\title{
PENGARUH PENAMBAHAN SERAT RAMI PADA TANAH TERJUN-MEDAN DENGAN PENGUJIAN STANDARD COMPACTION, TRIAXIAL UNCONSOLIDATED UNDRAINED, DAN PREDIKSI BALIK DENGAN PLAXIS 2D
}

\section{Handi Utama Thomas, Roesyanto, dan Rudi Iskandar}

Universitas Sumatera Utara, Medan, Indonesia

Email: handiutamathomas@gmail.com, roesyantos@yahoo.com, dan sipil.s2.usu@gmail.com

\begin{tabular}{l} 
INFO ARTIKEL \\
\hline Diterima \\
5 April 2021 \\
Direvisi \\
10 April 2021 \\
Disetujui \\
15 April 2021
\end{tabular}

\section{Keywords:}

jute fiber; triaxial uи; uct; cbr; plaxis $2 d$; harderning soil model

\begin{abstract}
Soil has an important role in construction. The bearing capacity of the soil must be able to withstand the load of the structure above it. Soft soil problems that are often encountered include damage to flexible and rigid pavements, embankment failure, slope failure, soil subsidence which causes structural damage. An environmentally friendly innovation is needed in handling soft soil in-situ in addition to considerations from an economic perspective, time and material availability. This study aims to determine the effect of adding jute fiber to the soil on the shear strength and maximum dry density of the soil. This study used jute fiber randomly mixed with soil with a jute content of $1 \%$, $2 \%, 3 \%, 4 \%$ and $5 \%$ of the weight of the soil then carried out a compaction test and Triaxial UU. The Triaxial UU test is carried out for soils with maximum fiber content. The results of this study showed that the maximum dry density $\left(\gamma_{\text {dmax }}\right)$ of the soil decreased along with the addition of jute fiber where the highest $\gamma_{\text {dmax }}$ was 1.595 $\mathrm{g} / \mathrm{cm}^{2}$ while the lowest $\gamma_{\text {dmax }}$ was $1.438 \mathrm{~g} / \mathrm{cm}^{3}$. The addition of $5 \%$ jute fiber resulted in an increase in the shear strength $\left(c_{u}\right)$ value of the Triaxial UU test by $477.1 \%$ from $1.05 \mathrm{~kg} / \mathrm{cm}^{2}$ to $5.01 \mathrm{~kg} / \mathrm{cm}^{2}$. The results of the Triaxial UU modeling with the harderning soil model in the Plaxis $2 D$ program are quite close to the results of laboratory tests with relatively the same deviatoric stress results.
\end{abstract}

\section{ABSTRAK}

Tanah mempunyai peranan yang penting dalam konstruksi. Daya dukung tanah wajib mampu menahan beban struktur di atasnya. Problematika tanah lunak yang

\begin{tabular}{ll}
\hline How to cite: & Thomas, Handi Utama (2021) Pengaruh Penambahan Serat Rami Pada Tanah Terjun-Medan Dengan \\
& Pengujian Standard Compaction, Triaxial Unconsolidated Undrained, Dan Prediksi Balik Dengan \\
& Plaxis 2d. Jurnal Syntax Admiration 2(4). https://doi.org/10.46799/jsa.v2i4.220 \\
E-ISSN: & $\frac{2722-5356}{\text { Ridwan Institute }}$ \\
Published by: &
\end{tabular}


Kata kunci:

serat rami; triaxial uu; uct; cbr; plaxis 2d; harderning soil model sering dijumpai seperti kerusakan jalan perkerasan lentur maupun kaku, kelongsoran timbunan, kelongsoran lereng, dan penurunan tanah yang menyebabkan kerusakan struktur. Diperlukan inovasi yang ramah lingkungan dalam penanganan tanah lunak tersebut secara in-situ disamping dengan pertimbangan dari segi ekonomis, waktu, dan ketersediaan material. Penelitian bertujuan untuk mengetahui pengaruh penambahan serat rami pada tanah terhadap kekuatan geser dan kepadatan kering maksimum tanah. Penelitian ini menggunakan serat rami yang dicampurkan secara acak dengan tanah dengan kadar rami sebesar 1\%, 2\%, 3\%, 4\% dan 5\% dari berat tanah kemudian dilakukan compaction test dan Triaxial UU. Pengujian Triaxial UU dilakukan untuk tanah dengan kandungan serat maksimum. Hasil penelitian ini yaitu kepadatan kering maksimum $\left(\gamma_{\mathrm{dmax}}\right)$ tanah mengalami penurunan seiring dengan penambahan serat rami dimana $\gamma_{\text {dmax }}$ tertinggi sebesar $1,595 \mathrm{~g} / \mathrm{cm}^{3}$ sedangkan $\gamma_{\text {dmax }}$ terendah sebesar $1,438 \mathrm{~g} / \mathrm{cm}^{3}$. Penambahan serat rami sebesar 5\% menghasilkan peningkatan pada nilai kekuatan geser $\left(\mathrm{c}_{\mathrm{u}}\right)$ hasil pengujian Triaxial $U U$ sebesar $477,1 \%$ dari $1,05 \mathrm{~kg} / \mathrm{cm}^{2}$ menjadi $5,01 \mathrm{~kg} / \mathrm{cm}^{2}$. Hasil pemodelan Triaxial UU dengan pemodelan harderning soil model pada program Plaxis 2D cukup mendekati dengan hasil pengujian laboratorim dengan hasil tegangan deviatorik yang relatif sama.

\section{Pendahuluan}

Tanah selalu mempunyai peranan yang penting pada suatu lokasi pekerjaan konstruksi. Tanah adalah pondasi pendukung suatu bangunan, atau bahan konstruksi dari bangunan itu sendiri. Oleh sebab itu, daya dukung dari tanah tersebut wajib mampu menahan beban struktur di atasnya. Dalam pengertian teknis, terminologi dari pada daya dukung tanah adalah kemampuan tanah memikul tekanan dan/atau melawan penurunan akibat pembebanan, yaitu tahanan geser yang disebarkan oleh tanah di sepanjang bidang-bidang gesernya (Darwis, 2018)

Perkembangan konstruksi yang sangat pesat di Indonesia dalam beberapa tahun terakhir seperti pembangunan jalan tol, bendungan, bandara, pelabuhan, reklamasi dan lain sebagainya tentunya memberikan tantangan tersendiri bagi pelaku konstruksi khususnya dalam bidang geoteknik (Kaushal, 2015). Dunia konstruksi di Indonesia umumnya tidak dapat terpisahkan dari tanah lunak dengan distribusi tanah lunak cukup tersebar luas di Indonesia dimana berada di sepanjang pantai utara Pulau Jawa, pantai timur Pulau Sumatera, pantai barat Pulau Kalimantan, pantai selatan Pulau Kalimantan, pantai timur Pulau Kalimantan, pantai selatan Pulau Sulawesi, pantai barat Pulau Papua dan pantai selatan Pulau Papua (Kuswanda, 2015). 
Problematika tanah lunak yang sering dijumpai seperti kerusakan timbunan badan jalan, kerusakan jalan perkerasan lentur maupun kaku, kelongsoran timbunan, kelongsoran lereng, kelongsoran dinding penahan tanah, penurunan tanah yang menyebabkan kerusakan struktur. Oleh sebab itu, diperlukan inovasi-inovasi yang ramah lingkungan dalam penanganan tanah lunak tersebut secara in-situ disamping dari melakukan replacement tanah dengan pertimbangan dari segi ekonomis, waktu, dan ketersediaan material (Sutomo et al., 2014).

Tanah yang berlokasi di daerah Terjun-Marelan diketahui memiliki daya dukung yang cukup rendah dan termasuk dalam kategori tanah lunak. Pada penelitian yang dilakukan dengan melakukan pengujian SPT pada daerah tersebut diperoleh dimana tanah pada kedalaman 0-8 meter memiliki nilai N-SPT sebesar 0 (Pronoto, 2020). Menurut Terzaghi and Peck, dengan nilai N-SPT $<2$ maka tanah termasuk dalam kategori very soft soil.

Tanah lunak memiliki karakteristik tanah yang buruk. Tanah ini umumnya memiliki sifat komprebilitas yang tinggi, permeabilitas yang rendah dan daya dukung yang rendah (Maliakal \& Thiyyakkandi, 2013). Tingginya tingkat komprebilitas pada tanah lunak disebabkan oleh angka pori yang tinggi. Jika tanah tersebut diberi beban, maka air maupun udara yang mengisi pori-pori tanah akan keluar sehingga terjadi pemampatan tanah yang menandakan adanya penurunan yang terjadi pada tanah (Pradana, 2018).

Seiring perkembangan zaman pembangunan muncul beberapa metode dalam perbaikan tanah tersebut yaitu dengan metode stabilisasi tanah. Menurut (Reddy \& Latha, 2014) stabilisasi tanah sebagai perubahan dari setiap properti tanah untuk memperbaiki engineering performance dari tanah tersebut. Secara garis besar klasifikasi tindakan stabilisasi tanah dapat dibedakan atas dua macam yaitu soil improvement dan soil reinforcement. Soil reinforcement merupakan suatu jenis stabilisasi tanah untuk memperbaiki dan mempertahankan kinerja tanah sesuai syarat teknis yang dibutuhkan dengan memberikan sisipan ke dalam lapisan tanah tersebut (Darwis, 2018)

Penelitian yang telah dilakukan oleh (Singh \& Bagra, 2013) dimana penelitian ini hanya melakukan pengujian CBR dengan persentase serat rami yang ditambahkan sebesar $0,25 \%, 0,50 \%, 0,75 \%$ dan $1,00 \%$, menghasilkan nilai CBR yang juga meningkat dengan peningkatan terbesar yaitu $200,49 \%$ pada persentase serat rami $1,00 \%$ dengan panjang serat $90 \mathrm{~mm}$.

Pengujian UCT pada tanah pasir halus dengan penambahan serat rami $0,5 \%$, $1,0 \%, 1,5 \%, 2,0 \%$ dengan panjang serat $20 \mathrm{~mm}$ menghasilkan nilai undrained shear strength mengalami peningkatan terbesar sebesar 172\% (Sharma et al., 2017).

Pada penelitian ini penulis menggunakan kandungan serat rami sebanyak 1\%, 2\%, $3 \%, 4 \%, 5 \%$ dan melakukan randomly mix pada tanah yang akan diuji kemudian dilakukan pengujian standard compaction dan Triaxial UU. Penelitian ini diharapkan dapat meningkatkan kuat geser tanah akibat dari penambahan serat rami sehingga diharapkan dapat menjadi salah satu referensi dalam hal perkuatan tanah dalam bidang geoteknik. 
Pengaruh Penambahan Serat Rami Pada Tanah Terjun-Medan Dengan Pengujian Standard Compaction, Triaxial Unconsolidated Undrained, Dan Prediksi Balik Dengan

Plaxis 2d

Adapun tujuan penulisan ini adalah untuk engetahui perbandingan nilai maximum dry density tanah tersebut antara tanah asli dan tanah yang diberikan tambahan serat rami dengan Compaction Test. Mengetahui perbandingan nilai parameter kekuatan tanah antara tanah asli dan tanah yang diberikan tambahan serat rami dengan pengujian Triaxial UU. Membandingkan hasil pemodelan simulasi Triaxial UU berdasarkan parameter yang diperoleh dari hasil laboratorium pada Plaxis 2D dengan pengujian Triaxial UU di laboratorium.

\section{Metode Penelitian}

Kegiatan penelitian yang dilakukan dalam penulisan ini meliputi studi literatur, pengambilan sampel di lapangan, persiapan benda uji, pengujian sifat-sifat fisis tanah asli, pengujian sifat mekanis tanah, pengolahan data hasil pengujian laboratorium, perbandingan parameter hasil pengujian Triaxial UU terhadap tanah asli dan tanah dengan campuran serat rami dan pemodelan pengujian Triaxial UU dengan aplikasi Plaxis 2D.

Pengambilan contoh tanah dari lokasi dilakukan pada beberapa titik dalam radius \pm 1 meter dengan mengambil 3 contoh tanah asli dengan shelby tube (tabung undisturbed) dan $+/-250 \mathrm{~kg}$ tanah terganggu dari hasil borrow-pits pada kedalaman $1 \mathrm{~m}$ dari muka tanah pada radius tersebut. Contoh tanah terganggu ini akan digunakan untuk pengujian atterberg limit, shieve analysis, hydrometer dan bahan pembuatan sample remoulded untuk pengujian Triaxial UU. Sementara untuk tanah tak terganggu (undisturbed) digunakan untuk pengujian water content dan bulk density tanah.

Pembuatan sampel untuk dilakukan pengujian compaction dilakukan untuk tanah dengan campuran serat rami sebanyak 0\%, 1\%, 2\%, 3\%, 4\% dan 5\%. Pengujian Triaxial UU dilakukan untuk tanah dengan kandungan serat rami terkecil dan terbesar yaitu $0 \%$ dan 5\% pada kondisi berat kering maksimum dan kadar air optimum tanah.

\section{Hasil dan Pembahasan}

A. Hasil Pengujian Index Properties

\section{Water content}

Pengujian kadar air diperlukan untuk mengetahui seberapa besar kandungan air yang terkandung dalam tanah tersebut. Pengujian kadar air menggunakan sampel tanah tidak terganggu (undisturbed sample). Dari hasil pengujian laboratorium hasil pengujian kadar air rata rata sebesar 35,09\% dan dapat dilihat pada Tabel 1.

\section{Tabel 1}

Hasil Pengujian Kadar Air

\begin{tabular}{cccc}
\hline Keterangan & UDS-01 & UDS-02 & UDS-03 \\
\hline Water Content $(\%)$ & 34,61 & 35,26 & 5,39 \\
Average Water Content $(\%)$ & & 35,09 & \\
\hline
\end{tabular}

Sumber: Hasil perhitungan

2. Berat isi 
Pengujian berat isi suatu tanah diperlukan untuk mengetahui bagaimana perbandingan berat per volume dari tanah tersebut. Pengujian ini menggunakan sampel tidak terganggu (undisturbed) (Nursar et al., 2016). Dari hasil pengujian laboratorium hasil pengujian berat isi rata rata sebesar $1,64 \mathrm{~g} / \mathrm{cm}^{3}$ dan dapat dilihat pada Tabel 2. Pengujian berat isi dapat dilihat pada Gambar 1.

\section{Tabel 1}

Hasil Pengujian Berat Isi

\begin{tabular}{cccc}
\hline Keterangan & UDS-01 & UDS-02 & UDS-03 \\
\hline Berat isi $\left(\mathrm{g} / \mathrm{cm}^{3}\right)$ & 1,64 & 1,65 & 1,63 \\
Berat isi rata-rata $\left(\mathrm{g} / \mathrm{cm}^{3}\right)$ & & 1,64 & \\
\hline
\end{tabular}

Sumber: Hasil perhitungan

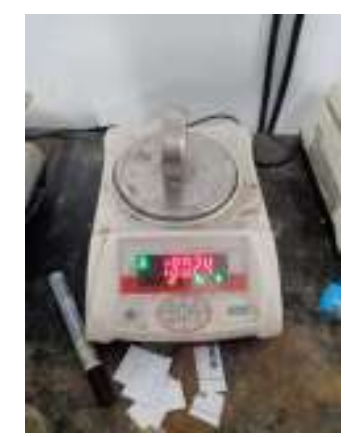

Gambar 1

\section{Pengujian Berat Isi}

3. Specific gravity

Nilai specific gravity dipengaruhi oleh kadar organik pada tanah, semakin banyak kadar organik pada tanah, maka nilai specific gravity akan semakin rendah. Nilai spesific gravity rata rata yang didapat dari laboratorium adalah sebesar 2,644. Pengujian spesific gravity dapat menggunakan sampel tanah terganggu (disturbed sample) (Prasetio \& Agus Susanto, 2017). Nilai spesific gravity untuk setiap sampel dapat dilihat pada Tabel 3. Pengujian spesific gravity dapat dilihat pada Gambar 2.

Tabel 2

Hasil Pengujian Spesific Gravity

\begin{tabular}{cccc}
\hline Keterangan & UDS-01 & UDS-02 & UDS-03 \\
\hline Spesific Gravity & 2,640 & 2,650 & 2,640 \\
Average Spesific Gravity & & 2,644 & \\
\hline
\end{tabular}

Sumber: Hasil perhitungan 
Pengaruh Penambahan Serat Rami Pada Tanah Terjun-Medan Dengan Pengujian Standard Compaction, Triaxial Unconsolidated Undrained, Dan Prediksi Balik Dengan Plaxis 2d

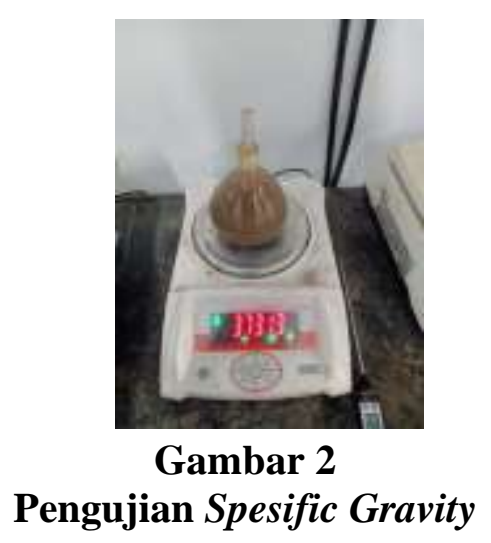

4. Batas Atterberg

Pada pengujian ini dilakukan dua jenis uji yaitu uji batas cair dan uji batas plastis. Pada pengujian batas cair sebanyak empat sampel diuji pada jumlah ketukan yang berbeda yaitu satu sampel diuji pada jumlah ketukan dengan rentang 15-25 ketukan, dua sampel untuk rentang 20-30 ketukan dan 1 sampel dengan rentang 25-35 ketukan, kemudian masing-masing sampel diuji kadar airnya (Ardianti et al., 2018). Gambaran pengujian dapat dilihat pada Gambar 3. Hasil pengujian kemudian diplot dalam bentuk grafik kadar air terhadap jumlah ketukan seperti pada Gambar 5, nilai batas cair yang diambil adalah berdasarkan jumlah 25 ketukan.

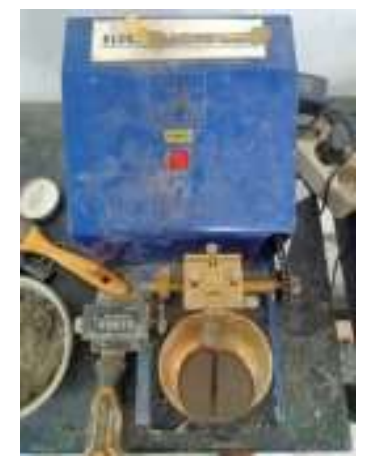

Gambar 3

Pengujian Batas Cair Sampel 116 Kali Pukulan

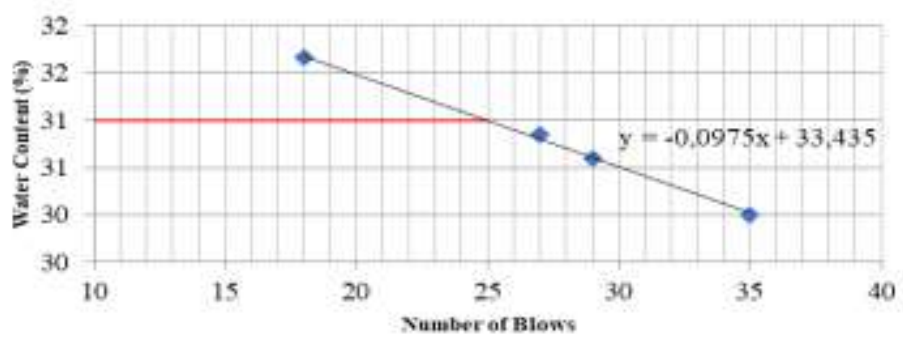

Gambar 4

Grafik Hasil Pengujian Batas Cair 
Pada pengujian batas plastis sebanyak 3 sampel diuji dengan menggulunggulung sampel uji hingga mencapai ketebalan sebesar $3 \mathrm{~mm}$ dan retak-retak secara visual kemudian diukur kadar airnya. Pada penelitian ini penulis melakukan batas atterberg sebanyak 3 sampel dimana besaran nilai batas cair dan batas plastis dapat dilihat pada Tabel 4.

\section{Tabel 3}

Rangkuman Hasil Pengujian Atterberg

\begin{tabular}{cccc}
\hline Keterangan & Sampel 1 & Sampel 2 & Sampel 3 \\
\hline Batas Plastis & 26,44 & 26,21 & 26,13 \\
Batas Cair & 30.78 & 32.36 & 33.67 \\
Indeks Plastisitas & 4,55 & 6,15 & 7,54 \\
\hline
\end{tabular}

Sumber: Hasil perhitungan

5. Analisa saringan dan hydrometer

Analisa saringan dan hydrometer bertujuan untuk menentukan ukuran ukuran partikel tanah yang diuji yang kemudian akan digunakan sebagai acuan dalam penentuan klasifikasi tanah. Klasifikasi tanah berguna untuk mengelompokkan tanah-tanah sesuai dengan prilaku umum dari tanah tertentu pada kondisi fisik.

Pada penelitian ini penulis melakukan pengujian analisa saringan dan hidrometer sebanyak 3 sampel. Untuk hasil pengujian analisa saringan diperoleh hasil persen lolos saringan No. $4(4,75 \mathrm{~mm})$ sebesar $100 \%$ untuk ketiga sampel tersebut, dan saringan No. $200(0,075 \mathrm{~mm})$ dengan persen lolos sebesar 69.68\% untuk sampel 1, 70.04\% untuk sampel 2 dan 68.72\% untuk sampel 3 atau dengan kata lain mayoritas komposisi tanah yang diuji adalah tanah berbutir halus

Untuk hasil pengujian hidrometer diperoleh ukuran partikel $<0,002 \mathrm{~mm}$ adalah sebesar 4,43\% untuk sampel 1, 4,43\% untuk sampel 2 dan 2,73\% untuk sampel 2,87\%. Pada Gambar 5 hingga Gambar 7 ditunjukkan grafik distribusi ukuran partikel tanah yang merupakan hasil dari pengujian ini. Dari hasil penelitian ini dapat diperoleh komposisi kerikil, pasir, lempung dan lanau seperti tampak pada Tabel 5 . 
Pengaruh Penambahan Serat Rami Pada Tanah Terjun-Medan Dengan Pengujian Standard Compaction, Triaxial Unconsolidated Undrained, Dan Prediksi Balik Dengan Plaxis 2d



Grafik Distribusi Ukuran Partikel Sampel 1

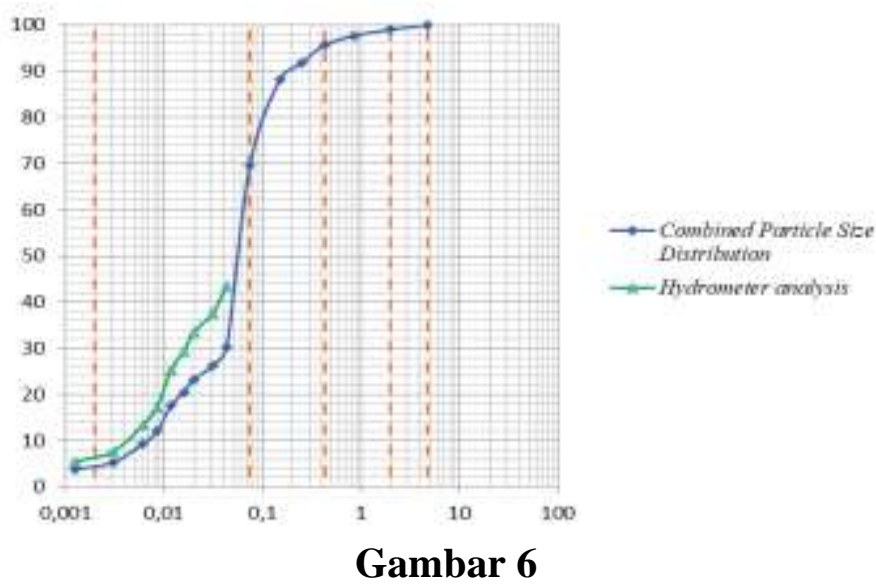

Grafik Distribusi Ukuran Partikel Sampel 2



Grafik Distribusi Ukuran Partikel Sampel 3 


\section{Tabel 4}

Rangkuman Hasil Distribusi Partikel

\begin{tabular}{ccccc}
\hline \multirow{2}{*}{ Jenis } & \multirow{2}{*}{ Ukuran } & \multicolumn{3}{c}{ Persentase (\%) } \\
& & Sampel & Sampel & Sampel \\
& & $\mathbf{1}$ & $\mathbf{2}$ & $\mathbf{3}$ \\
\hline Kerikil & $>4,750 \mathrm{~mm}$ (\# No.4) & 0 & 0 & 0 \\
Pasir & $4,750-0,075 \mathrm{~mm}$ (\# No. 200) & 30.32 & 29.96 & 31.28 \\
Lanau \& Lempung & $<0,075 \mathrm{~mm}$ (Lolos No.200) & 69.68 & 70.04 & 68.72 \\
\hline
\end{tabular}

Sumber: Hasil Perhitungan

6. Klasifikasi tanah

Dari hasil pengujian sifat fisis, tanah diklasifikasikan dengan menggunakan standar USCS (Unified Soil Classification System) dan AASHTO (American Association of State Highway and Transportation Official).

Dalam penentuan klasifikasi tanah menurut USCS terdapat beberapa tahapan, yaitu:

a. Mengacu pada Gambar 8 yaitu hasil dari pengujian batas Atterberg maka seluruh sampel pengujian termasuk kedalam kategori "ML".

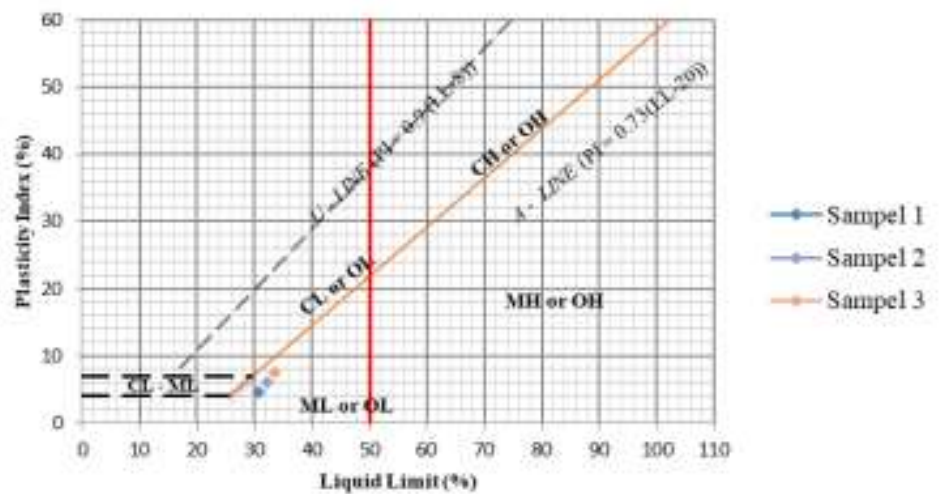

Gambar 8

Plastisitas Sistem USCS

b. Hasil pecime saringan dimana persentasi tanah yang lolos ayakan no.200 lebih besar dari 50\%, maka mengacu pada Tabel 5 dan Gambar 8 tanah pada penelitian ini menurut pecim USCS termasuk dalam klasifikasi sebagai tanah ML atau lanau berpasir dengan plastisitas rendah.

Penentuan klasifikasi tanah menurut AASHTO, yaitu:

a. Berdasarkan klasifikasi tanah menurut AASHTO, ketiga sampel tanah pada penelitian ini memiliki kriteria lolos saringan No. 200 lebih besar dari 35\% dan dapat digolongkan sebagai tanah berbutir halus dengan nilai batas cair, batas plastis dan indeks plastisitas sesuai dengan Tabel 5 maka menurut grafik plastisitas berdasarkan AASHTO pada Gambar 9 dan klasifikasi pada tabel klasifikasi tanah berbutir halus system AASTHO (Irawan et al., 2017) sampel dikategorikan sebagai A-4 atau tanah berlanau. 
Pengaruh Penambahan Serat Rami Pada Tanah Terjun-Medan Dengan Pengujian Standard Compaction, Triaxial Unconsolidated Undrained, Dan Prediksi Balik Dengan

Plaxis 2d

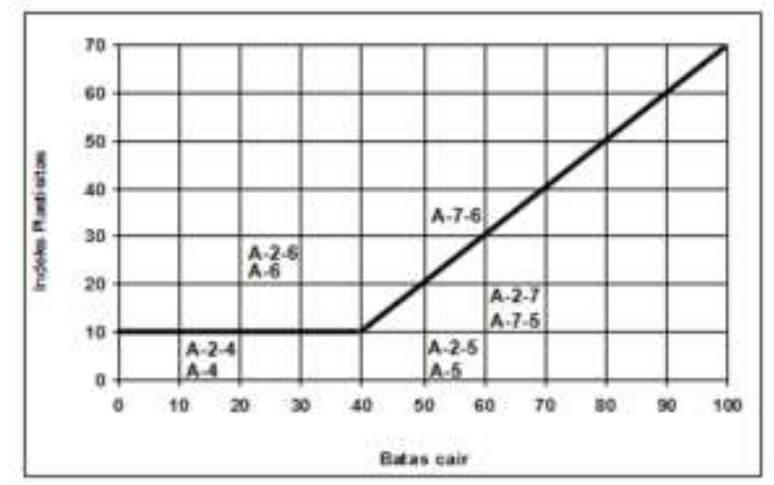

Gambar 9

Grafik Plastisitas Sistem Klasifikasi Berdasarkan AASHTO

B. Hasil Pengujian Engineering Properties

1. Pengujian Compaction with standard effort

Pengujian compaction with standard effort diperlukan untuk mendapatkan berat kering maksimum tanah dan kadar air optimum tanah. Pengujian ini dilakukan pada setiap variasi. Pengujian ini sebagai dasar untuk penentuan kadar air optimum tanah untuk setiap variasi yang nantinya digunakan untuk pembuatan benda uji untuk pengujian Triaxial UU (Sari \& Tambunan, 2020). Hasil pengujian compaction yang didapat dari penelitian ini dapat dilihat pada Tabel 6.

Tabel 5

Hasil Pengujian Compaction

\begin{tabular}{ccccccc}
\hline Keterangan & Var.1 & Var.2 & Var.3 & Var.4 & Var.5 & Var.6 \\
\hline Optimum moisture content $(\%)$ & 20,5 & 20,6 & 21,3 & 22,0 & 22,5 & 25,8 \\
Berat Kering Maksimum $\left(\mathrm{g} / \mathrm{cm}^{3}\right)$ & 1,595 & 1,575 & 1,53 & 1,491 & 1,475 & 1,438 \\
\hline
\end{tabular}

Sumber: Hasil Perhitungan

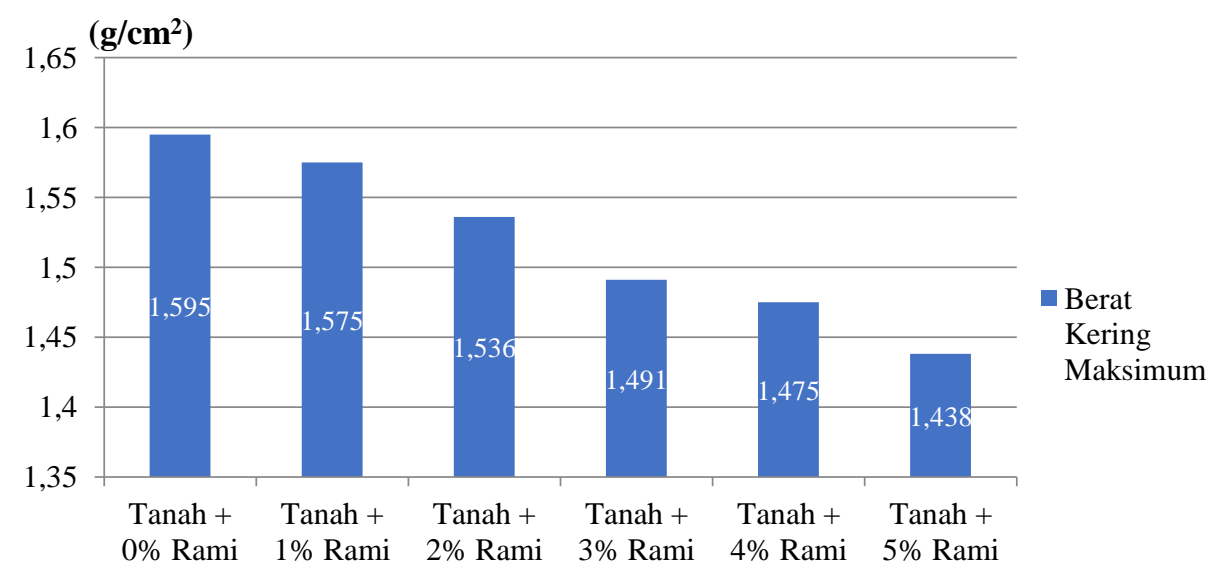

Gambar 10

Pengaruh Penambahan Serat Rami Terhadap Berat Kering Maksimum 
Dari data hasil pengujian tersebut dapat dilihat bahwa semakin banyak komposisi serat rami yang dicampurkan pada tanah tersebut, maka kadar air optimum memiliki kecenderungan bertambah sedangkan berat kering maksimum tanah memiliki kecenderungan menurun. Hal ini dipengaruhi oleh berat isi dari serat rami yang cukup ringan dan tingkat penyerapan air dari rami yang cukup tinggi. Grafik pengaruh penambahan serat rami terhadap hasil pengujian tersebut disajikan penulis pada Gambar 10.

2. Pengujian Triaxial Unconsolidated Undrained

Pengujian Triaxial yang dilakukan penulis pada penelitian kali ini adalah bersifat unconsolidated undrained dimana sampel tidak terkonsolidasi dan tidak teraliri. Pengujian ini berguna untuk mendapatkan parameter kuat geser tanah berupa shear pecimen, $\mathrm{c}_{\mathrm{u}}\left(\mathrm{kg} / \mathrm{cm}^{2}\right)$ dan angle of friction, $\phi_{\mathrm{u}}\left(^{\circ}\right)$ (Rahayu et al., 2015).

Konsep pengujian ini adalah dengan memberikan kekangan pada sampel sesuai dengan kondisi lapangan, kemudian memberikan pembebanan pada sampel secara aksial sampai kondisi keruntuhan sampel atau regangan maksimal $15 \%$. Pengujian triaksial UU, sampel tanah melalui beberapa tahapan yaitu tahap saturasi, tahap confining dan tahap pecimen c untuk masing-masing pecimen.

Variasi campuran yang dilakukan pengujian Triaxial UU pada penelitian ini adalah variasi campuran yang memiliki kadar rami minimum dan maksimum yaitu variasi 1 dimana tanah tanpa campuran rami dengan variasi 6 dimana tanah dicampur dengan $5 \%$ rami.

Hasil pengujian kedua variasi ini menunjukkan bahwa terjadi peningkatan kekuatan geser tanah yang cukup signifikan akibat penambahan serat rami pada tanah. Dimana pada variasi 1, nilai besaran $c_{u}$ yang diperoleh sebesar $1,05 \mathrm{~kg} / \mathrm{cm}^{2}$ sedangkan pada variasi 6 , nilai besaran $c_{u}$ yang diperoleh sebesar $5,01 \mathrm{~kg} / \mathrm{cm}^{2}$ seperti yang terlihat pada Tabel 7 .

\section{Tabel 7}

Hasil Pengujian Triaxial UU Variasi 0\% Rami dan Variasi 5\% Rami

\begin{tabular}{ccccccc}
\hline \multirow{2}{*}{ Keterangan } & \multicolumn{3}{c}{ Tanah + 0\% Rami } & \multicolumn{3}{c}{ Tanah + 5\% Rami } \\
& $\sigma_{\mathbf{3 1}}$ & $\boldsymbol{\sigma}_{\mathbf{3 2}}$ & $\boldsymbol{\sigma}_{\mathbf{3 3}}$ & $\boldsymbol{\sigma}_{\mathbf{3 1}}$ & $\boldsymbol{\sigma}_{\mathbf{3 2}}$ & $\boldsymbol{\sigma}_{\mathbf{3 3}}$ \\
\hline $\begin{array}{c}\text { Max. Deviatorik } \\
\text { stress }\left(\mathrm{kg} / \mathrm{cm}^{2}\right)\end{array}$ & 2,05 & 2,115 & 2,133 & 9,93 & 10,04 & 10,06 \\
$\begin{array}{c}\text { Strain at maximum } \\
\text { stress }(\%)\end{array}$ & 15,00 & 14,2 & 11,7 & 15,00 & 14,70 & 7,00 \\
$\mathrm{c}_{\mathrm{u}}\left(\mathrm{kg} / \mathrm{cm}^{2}\right)$ & & 1,05 & & & 5,01 & \\
\hline
\end{tabular}

Sumber: Hasil Perhitungan

Dari Tabel 7 dapat dilihat bahwa tegangan deviatorik antara spesimen yang satu dengan yang lainnya masih memiliki perbedaan meskipun perbedaan nilainya tergolong sangat kecil. Hal ini dikarenakan sampel yang diuji tidak jenuh $100 \%$. Seluruh sampel yang diuji memiliki derajat kejenuhan $\geq 95 \%$ karena diperlukan 
Pengaruh Penambahan Serat Rami Pada Tanah Terjun-Medan Dengan Pengujian Standard Compaction, Triaxial Unconsolidated Undrained, Dan Prediksi Balik Dengan

Plaxis 2d

waktu yang dibutuhkan cukup lama untuk menjenuhkan sampel. Menurut ASTM D2850 - Standard test method for unconsolidated-undrained Triaxial compression test on cohesive soils suatu sampel sudah didefinisikan sebagai sampel jenuh apabila nilai derajat kejenuhan (Skempton) B $\geq 95 \%$.

Adapun perbandingan grafik tegangan terhadap regangan antara sampel tanah yang tanpa diberikan serat rami dengan sampel yang diberikan 5\% serat rami dapat dilihat pada Gambar 11.

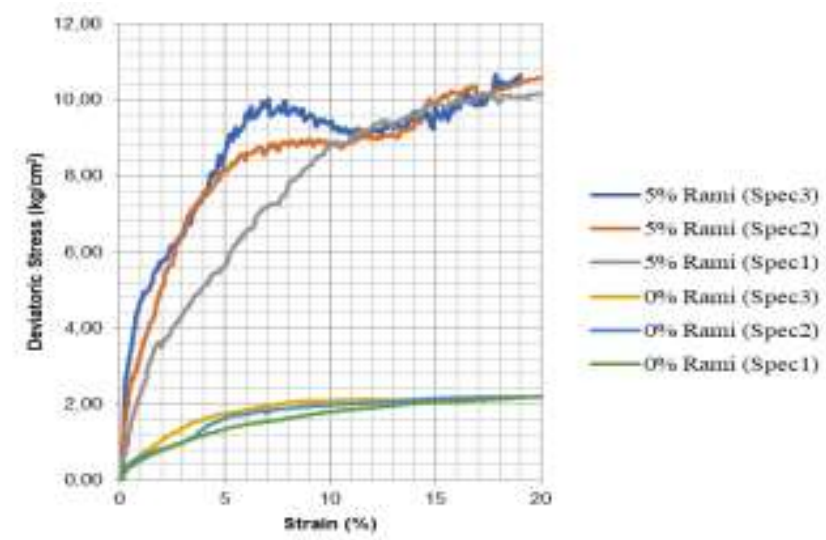

Gambar 11

Grafik Perbandingan Tegangan-Regangan Triaxial $U U$

3. Hasil pemodelan balik dengan program Plaxis 2D

Pada penelitian ini, penulis melakukan pemodelan pengujian Triaxial UU yang dilakukan pada laboratorium dimodelkan pada program Plaxis 2D. Pemodelan dilakukan dengan cara melakukan prediksi balik dari data parameter parameter yang didapatkan pada hasil uji laboratorium untuk mendapatkan grafik tegangan-regangan pengujian Triaxial UU.

Pada Plaxis 2D ini penulis menggunakan tipe asimetris dengan pemodelan harderning soil model dan jenis material undrained mengingat pengujian Triaxial yang dilakukan bersifat undrained. Adapun tahapan perhitungan pada program Plaxis adalah tahap intial condition, tahap confining, dan tahap deviatorik.

Gambar 12 hingga Gambar 17 menunjukkan bahwa perbedaan hasil tegangan-regangan dan tegangan deviatorik dari pengujian Triaxial di laboratoium dengan simulasi pengujian pada program Plaxis.

Gambar 12 menunjukkan grafik tegangan-regangan pada confining (cell pressure) $50 \mathrm{kN} / \mathrm{m}^{2}$ untuk tanah tanpa penambahan rami. Hasil program Plaxis model Harderning Soil menunjukkan bahwa regangan pada saat tegangan maksimum lebih besar dari hasil pengujian laboratorium sedangkan nilai tegangan maksimum lebih kecil dari pengujian laboratorium. Dari Gambar 12 didapat bahwa:

1. Uji Laboratorium

Tegangan Deviatorik maksimum sebesar $205 \mathrm{kN} / \mathrm{m}^{2}$ pada regangan 0,15 
2. Pemodelan Plaxis Harderning Soil Model Tegangan Deviatorik maksimum sebesar $196 \mathrm{kN} / \mathrm{m}^{2}$ pada regangan 0,15

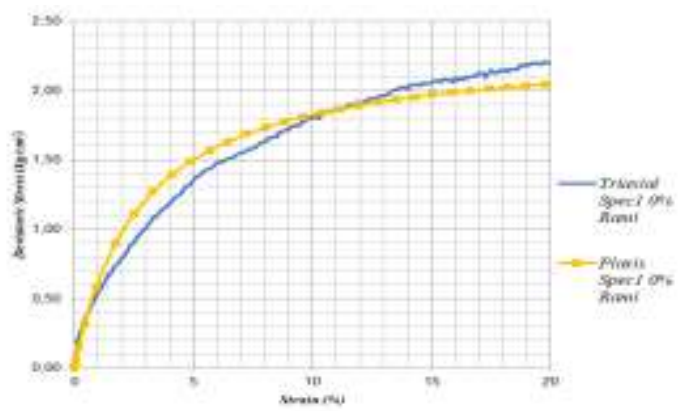

Gambar 12

Grafik Perbandingan Tegangan-Regangan Pengujian Triaxial UU Tanah + $0 \%$ Rami $\left(\sigma_{c}=0,5 \mathrm{~kg} / \mathrm{cm}^{2}\right)$ di Laboratorium dengan Plaxis $2 D$

Gambar 12 menunjukkan grafik tegangan-regangan pada confining (cell pressure) $100 \mathrm{kN} / \mathrm{m}^{2}$ untuk tanah tanpa penambahan rami. Hasil program Plaxis model Harderning Soil menunjukkan bahwa regangan pada saat tegangan maksimum sama dengan hasil pengujian laboratorium dan nilai tegangan maksimum lebih kecil dari pengujian laboratorium. Dari Gambar 12 didapat bahwa:

1. Uji Laboratorium

Tegangan Deviatorik maksimum sebesar $211 \mathrm{~kg} / \mathrm{cm}^{2}$ pada regangan 0,15

2. Pemodelan Plaxis Harderning Soil Model

Tegangan Deviatorik maksimum sebesar $197 \mathrm{~kg} / \mathrm{cm}^{2}$ pada regangan 0,15

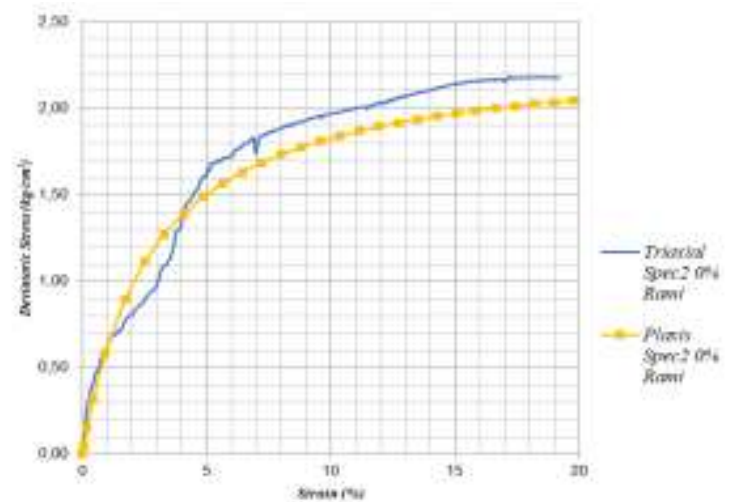

Gambar 13

Grafik Perbandingan Tegangan-Regangan Pengujian Triaxial UU Tanah + $0 \%$ Rami $\left(\sigma_{c}=1,0 \mathrm{~kg} / \mathrm{cm}^{2}\right)$ di Laboratorium dengan Plaxis $2 D$

Gambar 13 menunjukkan grafik tegangan-regangan pada confining (cell pressure) $200 \mathrm{kN} / \mathrm{m}^{2}$ untuk tanah tanpa penambahan rami. Hasil program Plaxis model Harderning Soil menunjukkan bahwa regangan pada saat tegangan maksimum sama dengan hasil pengujian laboratorium dan nilai tegangan 
Pengaruh Penambahan Serat Rami Pada Tanah Terjun-Medan Dengan Pengujian Standard Compaction, Triaxial Unconsolidated Undrained, Dan Prediksi Balik Dengan

Plaxis 2d

maksimum lebih kecil dari pengujian laboratorium. Dari Gambar 14 didapat bahwa:

1. Uji Laboratorium

Tegangan Deviatorik maksimum sebesar $211 \mathrm{kN} / \mathrm{m}^{2}$ pada regangan 0,12 .

2. Pemodelan Plaxis Harderning Soil Model

Tegangan Deviatorik maksimum sebesar $198 \mathrm{kN} / \mathrm{m}^{2}$ pada regangan 0,15.



Gambar 14

Grafik Perbandingan Tegangan-Regangan Pengujian Triaxial UU Tanah + $0 \%$ Rami $\left(\sigma_{c}=2,0 \mathrm{~kg} / \mathrm{cm}^{2}\right)$ di Laboratorium dengan Plaxis $2 D$

Gambar 14 menunjukkan grafik tegangan-regangan pada confining (cell pressure) $50 \mathrm{kN} / \mathrm{m}^{2}$ untuk tanah tanpa penambahan rami. Hasil program Plaxis model Harderning Soil menunjukkan bahwa regangan pada saat tegangan maksimum lebih besar dari hasil pengujian laboratorium sedangkan nilai tegangan maksimum lebih kecil dari pengujian laboratorium. Dari Gambar 14 didapat bahwa:

1. Uji Laboratorium

Tegangan Deviatorik maksimum sebesar $993 \mathrm{kN} / \mathrm{m}^{2}$ pada regangan 0,15

2. Pemodelan Plaxis Harderning Soil Model

Tegangan Deviatorik maksimum sebesar $964 \mathrm{kN} / \mathrm{m}^{2}$ pada regangan 0,15

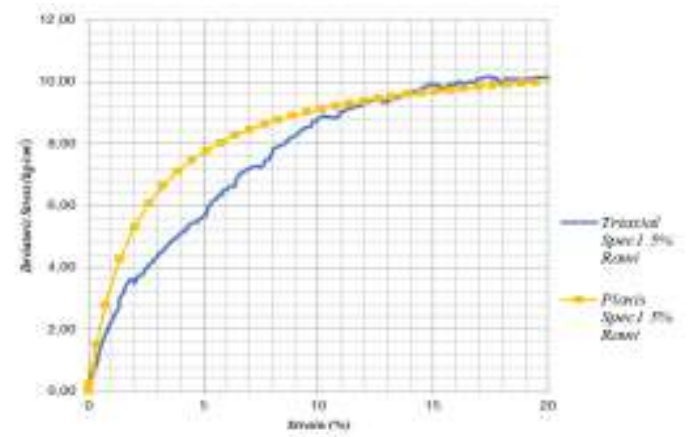

Gambar 15

Grafik Perbandingan Tegangan-Regangan Pengujian Triaxial UU Tanah $+5 \%$

Rami $\left(\sigma_{c}=0,5 \mathrm{~kg} / \mathrm{cm}^{2}\right)$ di Laboratorium dengan Plaxis $2 D$

Gambar 15 menunjukkan grafik tegangan-regangan pada confining (cell pressure) $100 \mathrm{kN} / \mathrm{m}^{2}$ untuk tanah tanpa penambahan rami. Hasil program Plaxis model Harderning Soil menunjukkan bahwa regangan pada saat tegangan maksimum sama dengan hasil pengujian laboratorium dan nilai tegangan 
maksimum lebih kecil dari pengujian laboratorium. Dari Gambar 15 didapat bahwa:

1. Uji Laboratorium

Tegangan Deviatorik maksimum sebesar $1003 \mathrm{kN} / \mathrm{m}^{2}$ pada regangan 0,15 .

2. Pemodelan Plaxis Harderning Soil Model

Tegangan Deviatorik maksimum sebesar $967 \mathrm{kN} / \mathrm{m}^{2}$ pada regangan 0,15.

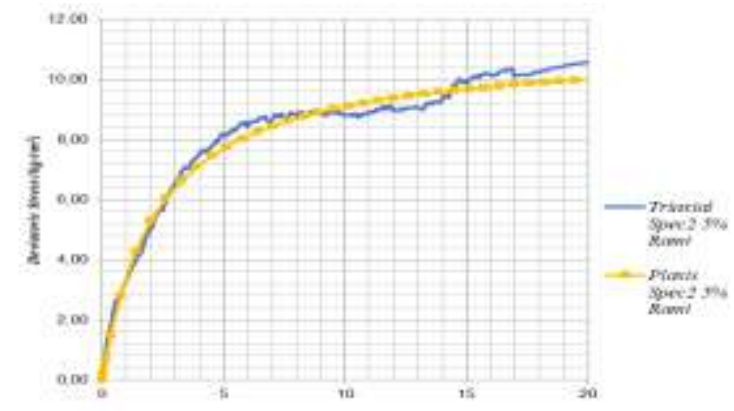

Gambar 16

Grafik Perbandingan Tegangan-Regangan Pengujian Triaxial UU Tanah $+5 \%$ Rami $\left(\sigma_{c}=0,5 \mathrm{~kg} / \mathrm{cm}^{2}\right)$ di Laboratorium dengan Plaxis $2 D$

Gambar 16 menunjukkan grafik tegangan-regangan pada confining (cell pressure) $200 \mathrm{kN} / \mathrm{m}^{2}$ untuk tanah tanpa penambahan rami. Hasil program Plaxis model Harderning Soil menunjukkan bahwa regangan pada saat tegangan maksimum sama dengan hasil pengujian laboratorium sedangkan nilai tegangan maksimum lebih kecil dari pengujian laboratorium. Dari Gambar 16 didapat bahwa:

1. Uji Laboratorium

Tegangan Deviatorik maksimum sebesar $1006 \mathrm{kN} / \mathrm{m}^{2}$ pada regangan 0,07

2. Pemodelan Plaxis Harderning Soil Model

Tegangan Deviatorik maksimum sebesar $969 \mathrm{kN} / \mathrm{m}^{2}$ pada regangan 0,15

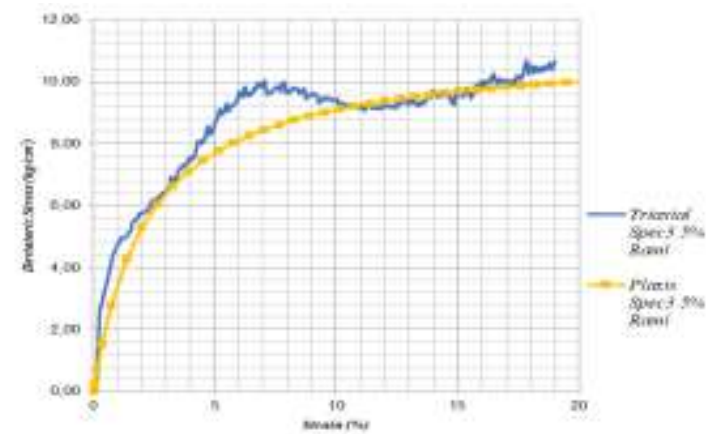

Gambar 17

Grafik Perbandingan Tegangan-Regangan Pengujian Triaxial UU Tanah $+5 \%$

Rami $\left(\sigma_{c}=0,5 \mathrm{~kg} / \mathrm{cm}^{2}\right)$ di Laboratorium dengan Plaxis $2 \mathrm{D}$

Dari hasil penelitian ini menunjukkan bahwa terjadi kenaikan nilai kekuatan geser tanah dan terjadi penurunan nilai kepadatan maksimum tanah akibat dari pengaruh penambahan serat rami. 
Pengaruh Penambahan Serat Rami Pada Tanah Terjun-Medan Dengan Pengujian Standard Compaction, Triaxial Unconsolidated Undrained, Dan Prediksi Balik Dengan

Plaxis 2d

Penelitian sebelumnya yang melakukan pengujian parameter kekuatan geser tanah yaitu penelitian yang dilakukan (Sharma et al., 2017) yang melakukan pengujian UCT pada tanah pasir halus dengan penambahan serat rami $0,5 \%, 1,0 \%, 1,5 \%, 2,0 \%$ dengan panjang serat $20 \mathrm{~mm}$ menghasilkan nilai undrained shear strength mengalami peningkatan terbesar sebesar $172 \%$ sedangkan penelitian yang menggunakan pengujian Triaxial $C U$ dilakukan (Singh \& Bagra, 2013) dimana penelitian ini meneliti pengaruh penambahan serat rami $0,25 \%, 0,5 \%, 0,75 \%$ dan $1,00 \%$ pada tanah dengan pengujian Triaxial $C U$, dimana hasil yang diperoleh yaitu terjadi peningkatan nilai kohesi sebesar $311 \%$ dan sudut geser $41 \%$ pada kandungan rami maksimum yaitu $1 \%$ dengan diameter $2 \mathrm{~mm}$.

Pada penelitian ini penulis memperoleh peningkatan nilai kohesi dari pengujian Triaxial UU sebesar 477,14\% untuk kandungan serat rami 5\% dengan diameter $2 \mathrm{~mm}$. Nilai deviatorik dan kurva strain-stress dari pemodelan Triaxial UU dengan pemodelan harderning soil model pada program Plaxis 2D juga memperoleh hasil yang cukup menyerupai dengan hasil pengujian Triaxial UU pada laboratorium. Hasil ini sejalan dengan penelitian yang dilakukan Tarigan (2012) dimana pemodelan yang digunakan dengan menggunakan soft soil model.

Dengan adanya penelitian ini penulis berharap penelitian ini dapat menjadi salah satu bahan referensi dalam metode perkuatan tanah sehingga dapat menyelesaikan masalah masalah geoteknik dalam konstruksi. Beberapa aplikasi dalam bidang geoteknik yang diharapkan dapat dilakukan adalah dengan adanya peningkatan nilai undrained shear strength atau parameter kuat geser tanah maka diharapkan dapat mengatasi masalah longsor yang diakibatkan kekuatan geser tanah yang rendah, pengaplikasiannya pada pada lereng sebagai bahan perkuatan lereng ataupun timbunan serta pengaplikasian pada kasus perkuatan tanah yang digunakan sebagai pondasi dangkal

\section{Kesimpulan}

Dari analisis yang telah dilakukan, maka dapat di buat beberapa kesimpulan yaitu Sampel tanah yang diuji berdasarkan klasifikasi menurut USCS masuk ke dalam klasifikasi ML yaitu: lanau berpasir dengan plastisitas rendah dan menurut klasifikasi aashto sampel tanah masuk dalam klasifikasi A-4 atau tanah berlanau. Pada pengujian compaction with standard effort diperoleh penurunan kepadatan kering maksimum dan kenaikan kadar air optimum seiring dengan bertambahnya kandungan serat rami yang ditambahkan pada tanah. dimana pada tanah tanpa campuran serat rami nilai kepadatan kering maksimum yang diperoleh sebesar $1,595 \mathrm{~g} / \mathrm{cm}^{3}$ dengan kadar air optimum sebesar 20,5\% sedangkan pada tanah dengan campuran serat rami maksimum sebesar $5 \%$ diperoleh nilai kepadatan kering maksimum sebesar $1,438 \mathrm{~g} / \mathrm{cm}^{3}$ dengan kadar air optimum sebesar 25,8\%. Pada pengujian Triaxial UU juga terjadi peningkatan undrained shear strength $\left(\mathrm{c}_{\mathrm{u}}\right)$ pada tanah akibat pengaruh dari penambahan serat rami. dimana nilai undrained shear strength $\left(\mathrm{c}_{\mathrm{u}}\right)$ pada tanah tanpa campuran serat rami sebesar $1,05 \mathrm{~kg} / \mathrm{cm}^{2}$ sedangkan pada tanah dengan campuran serat rami 5\% sebesar 5,01 
$\mathrm{kg} / \mathrm{cm}^{2}$. terjadi peningkatan sebesar $477,14 \%$ akibat pengaruh dari penambahan serat rami 5\% pada tanah tersebut. Analisis dengan program Plaxis 2D dengan pemodelan harderning soil model dimana bertujuan untuk memodelkan pengujian triaxial uu, diperoleh tegangan deviatorik dan grafik stress-strain yang mendekati dengan pengujian di laboratorium. dimana analisis yang dilakukan pada tanah tanpa campuran serat rami diperoleh tegangan deviatorik untuk spesimen $\sigma_{31}, \sigma_{32}$, dan $\sigma_{33}$ sebesar $1,95 \mathrm{~kg} / \mathrm{cm}^{2}, 1,97$ $\mathrm{kg} / \mathrm{cm}^{2}$ dan $1,98 \mathrm{~kg} / \mathrm{cm}^{2}$ sedangkan dari hasil pengujian laboratorium diperoleh tegangan deviatorik maksimum spesimen $\sigma_{31}, \sigma_{32}$, dan $\sigma_{33}$ berturut turut sebesar $2,05 \mathrm{~kg} / \mathrm{cm}^{2}, 2,11$ $\mathrm{kg} / \mathrm{cm}^{2}, 2,13 \mathrm{~kg} / \mathrm{cm}^{2}$. Dari analisis yang dilakukan pada tanah dengan campuran serat rami sebanyak $5 \%$ diperoleh tegangan deviatoric untuk spesimen $\sigma_{31}, \sigma_{32}$, dan $\sigma_{33}$ sebesar $9,64 \mathrm{~kg} / \mathrm{cm}^{2}, 9,67 \mathrm{~kg} / \mathrm{cm}^{2}$, dan $9,69 \mathrm{~kg} / \mathrm{cm}^{2}$ sedangkan dari hasil pengujian laboratorium diperoleh tegangan deviatorik maksimum untuk spesimen $\sigma_{31}$, $\sigma_{32}$, dan $\sigma_{33}$ berturut turut sebesar $9,934 \mathrm{~kg} / \mathrm{cm}^{2}, 10,03 \mathrm{~kg} / \mathrm{cm}^{2}, 10,06 \mathrm{~kg} / \mathrm{cm}^{2}$. 
Pengaruh Penambahan Serat Rami Pada Tanah Terjun-Medan Dengan Pengujian Standard Compaction, Triaxial Unconsolidated Undrained, Dan Prediksi Balik Dengan

Plaxis 2d

\section{BIBLIOGRAFI}

Ardianti, R., Haza, Z. F., \& Sulistyorini, D. (2018). Stabilisasi Tanah Lempung Ekspansif Dengan Campuran Abu Sekam Padi Dan Kapur Padam Terhadap Uji Batas-Batas Atterberg. Renovasi: Rekayasa Dan Inovasi Teknik Sipil, 3(1), 27-39. Google Scholar

Darwis, H. (2018). Dasar-Dasar Mekanika Tanah. Yogyakarta: Pena Indis. Google Scholar

Irawan, S., Subagio, B., Hariyadi, E., \& Gerardo, F. (2017). Evaluasi Struktural Perkerasan Kaku Menggunakan Metoda Aashto 1993 Dan Metoda Austroads 2011 Studi Kasus: Jalan Cakung-Cilincing. Jurnal Teknik Sipil, 24(2), 173-182. Google Scholar

Kaushal, V. (2015). Influence Of Jute Fibres On The Unconfined And Compressive Strength Of Alkaline Soil. Journal Of Civil Engineering And Environmental Technology, 2(4), 335-338. Google Scholar

Kuswanda, W. P. (2015). Problematika Pembangunan Infrastuktur Pada Tanah Lempung Lunak Dan Alternatif Metoda Penanganannya. Info-Teknik, 270-288. Google Scholar

Maliakal, T., \& Thiyyakkandi, S. (2013). Influence Of Randomly Distributed Coir Fibers On Shear Strength Of Clay. Geotechnical And Geological Engineering, 31(2), 425-433. Google Scholar

Nursar, A. S., Iswan, I., \& Setyanto, S. (2016). Komparasi Nilai Daya Dukung Tanah Lempung Ditinjau Dari Hasil Uji Skala Penetrasi Konus Dinamis, Uji Cbr Laboratorium Dan Uji Kuat Tekan Bebas. Jurnal Rekayasa Sipil Dan Desain, 3(2), 193-204. Google Scholar

Pradana, T. F. (2018). Pengaruh Penambahan Serat Fiberglass Sebagai Bahan Campuran Untuk Memperkuat Timbunan Tanah Lempung. Sondir, 2(2), 1-14. Google Scholar

Prasetio, S., \& Agus Susanto, S. T. (2017). Kuat Dukung Tanah Lempung Bayat Klaten Yang Distabilisasi Dengan Tras. Universitas Muhammadiyah Surakarta. Google Scholar

Pronoto, A. (2020). Studi Perbandingan Parameter Kekuatan Geser Triaksial (Cu) Multi-Stage Dengan Single-Stage Untuk Tanah Dengan Klasifikasi Mh Atau A-7-5 (25). Google Scholar

Rahayu, W., Lisdiyanti, P., \& Pratama, R. E. (2015). Tanah Gambut Melalui Uji Triaksial Consolidated Undrained Dan Unconsolidated Undrained. Jurnal Teknik Sipil Itb, 22(3), 201-208. Google Scholar 
Handi Utama Thomas, Roesyanto, dan Rudi Iskandar

Reddy, B. V. V., \& Latha, M. S. (2014). Retrieving Clay Minerals From Stabilised Soil Compacts. Applied Clay Science, 101, 362-368. Google Scholar

Sari, K. I., \& Tambunan, L. (2020). Studi Perbandingan Uji Pemadatan Standar Dan Uji Pemadatan Modified Terhadap Tanah Dari Jalan Pertahanan-Patumbak Yang Dicampur Kapur. Jcebt (Journal Of Civil Engineering, Building And Transportation), 4(1), 22-30. Google Scholar

Sharma, L. K., Umrao, R. K., Singh, R., Ahmad, M., \& Singh, T. N. (2017). Geotechnical Characterization Of Road Cut Hill Slope Forming Unconsolidated Geo-Materials: A Case Study. Geotechnical And Geological Engineering, 35(1), 503-515. Google Scholar

Singh, H. P., \& Bagra, M. (2013). Improvement In Cbr Value Of Soil Reinforced With Jute Fiber. International Journal Of Innovative Research In Science, Engineering And Technology, 2(8), 3447-3452. Google Scholar

Sutomo, A. H., Soeyoko, S., \& Damanik, D. M. (2014). Sanitation Of House And School, Personal Hygiene And Infection Of Soil Transmitted Helminths Among Elementary School Students. International Journal Of Public Health Science, 3(1), 7172. Google Scholar

\section{Copyright holder :}

Handi Utama Thomas, Roesyanto, dan Rudi Iskandar (2021)

First publication right :

Journal Syntax Admiration

This article is licensed under: 